NBER WORKING PAPER SERIES

THE 1991 REFORMS, INDIAN ECONOMIC GROWTH, AND SOCIAL PROGRESS

\author{
Manmohan Agarwal \\ John Whalley \\ Working Paper 19024 \\ http://www.nber.org/papers/w19024
}

NATIONAL BUREAU OF ECONOMIC RESEARCH
1050 Massachusetts Avenue
Cambridge, MA 02138

May 2013

This paper forms part of the research on a project on China and the BRICs conducted under support from the Ontario Research Fund. We are grateful to a seminar group at Western Ontario for comments. The views expressed herein are those of the authors and do not necessarily reflect the views of the National Bureau of Economic Research.

NBER working papers are circulated for discussion and comment purposes. They have not been peerreviewed or been subject to the review by the NBER Board of Directors that accompanies official NBER publications.

(C) 2013 by Manmohan Agarwal and John Whalley. All rights reserved. Short sections of text, not to exceed two paragraphs, may be quoted without explicit permission provided that full credit, including (C) notice, is given to the source. 
The 1991 Reforms, Indian Economic Growth, and Social Progress

Manmohan Agarwal and John Whalley

NBER Working Paper No. 19024

May 2013

JEL No. E20,F10,F30,O40

\begin{abstract}
This paper analyzes the effects of the reforms initiated in India following the balance of payments (BOP) crisis of 1991 on economic performance. We do not find persuasive the contention of many analysts that growth accelerated after the mid-1980s when reforms were initiated. Nor does statistical analysis support the contention that reforms in the mid-1980s resulted in a growth acceleration. We show that there is an accelerating rate of growth of GDP after the mid 1970s and it is difficult to relate this gradual acceleration to specific policy changes. The changed policies in the 1980s did not mean a basic change in the policy framework. Furthermore, since corporate investment as a share of GDP did not increase in the 1980s it is difficult to identify the mechanism by which the more pro-business policies of the government were translated to higher growth.
\end{abstract}

We also find that the differences with East Asia and particularly China depend on the basis of the comparison. We compare changes in performance since the reforms, which started in China in 1979 and in India in 1991. Such a comparison shows more similarities than differences. We finally examine social progress. We find that South Asia lags behind other regions in making progress towards the Millennium Development Goals (MDGs) and India lags behind other South Asian countries. The responsiveness of the improvement in the MDGs to increases in per capita income is usually low in Asia and particularly in India.

\author{
Manmohan Agarwal \\ Center for International Governance Innovation (CI \\ 57 Erb St. West \\ Waterloo, ON \\ Canada N2L 6C2 \\ magarwal@cigionline.org \\ John Whalley \\ Department of Economics \\ Social Science Centre \\ University of Western Ontario \\ London, ON N6A 5C2 \\ CANADA \\ and NBER \\ jwhalley@uwo.ca
}




\section{Section I Introduction}

This paper analyzes the effects of the reforms initiated in India following the balance of payments (BOP) crisis of 1991 on the development strategy adopted by the government, its policies and the actual economic performance. We first discuss in Section II the significance of the 1991 reforms as there is a debate on when reforms started, as a number of analysts claim that reforms started in the mid-eighties and that is why growth started accelerating in the 1980s. We next examine the features of India's growth. India's growth experience is often contrasted with that of East Asia and more particularly China. It is claimed that savings rates though increasing are considerably lower than in East Asia; growth in India is based on the services sector rather than manufacturing which was the leading sector in East Asia; and again unlike East Asia India has not attracted much foreign direct investment (FDI) (Kotwal, Ramaswami and Wadhwa, 2011).

We argue below in Section II that while there were certain changes in policies in the 1980 s as there had been in earlier years, these did not mean a basic change in the policy framework. The resilience of the economy as it recovered quickly from economic crises encouraged the government to persist with the import substituting industrialization strategy it had adopted. However, research conclusions of various committees set up by the government to study the effects of licensing and import controls and the experience of other countries especially China resulted in policy makers believing that a change in the growth model was needed and the 1991 crisis provided the opportunity to carry out such a chnage. We show that there is an accelerating rate of growth of GDP after the mid 1970s and it is difficult to relate this gradual acceleration to specific policy changes. Furthermore, since corporate investment as a share of 
GDP did not increase in the 1980s it is difficult to identify the mechanism by which the more pro-business policies of the government were translated into higher growth as claimed by Rodrik and Subramaniam (2005).

In Section III we examine the claims that growth in India was more fuelled by domestic demand and less outwardly oriented than say in China, and, also, that it is more service oriented. We show that increasing exports of goods, non-factor services, and labour services, through remittances, have played an important role. Furthermore, the share of exports of goods and services grew as rapidly in India as in China. Also, there is no significant difference between the growth rates of value-added in the manufacturing and services sectors except for the period of the Ninth Plan (1997-2001). The increased value of exports of manufactures was important as their value grew from about 16 percent of the manufacturing sector's value added in the early 1980 s to about 60 percent currently.

In Section IV we examine the behavior of 12 economic indicators and find that most show improved performance in the decade 2001-10 relative to the earlier decade 1981-1990. The better performance consisted both in the level and lower variability. Furthermore, we find that the reforms had a gradual effect; the change in the period 1992-2000 was smaller and statistically less significant. While exports of goods increased, imports increased even faster so the deficit on the balance of trade in goods became larger; ${ }^{1}$ but was usually covered by an increasing surplus on service trade and the rise in remittances. However, since the financial crisis this has not been the case and the current account deficit has increased considerably. For most of the period private capital inflows were larger than the current account deficit leading to reserve

\footnotetext{
1 The importance of India as an importer of goods in the international market grew more rapidly relative to its income than China's leading to India usually running a deficit on merchandise trade while China ran a surplus.
} 
accumulation. Increasing trade along with rising private capital flows, both inward and outward, reflects the increasing integration of India with the world economy.

We also find in section IV that the differences with East Asia and particularly China depend on the basis of the comparison. This can be seen if we take into account that the reforms in China started in 1979 and in India in 1991 and that the staring points in these two years were very different for the two countries. Such a comparison shows more similarities than differences. For instance, the share of services in GDP increased between 1974-82 and 2001-10 by more than 85 percent in China and only 32 percent in India (Agarwal and Whalley, 2013). However, the share of services was much higher in India in 1992 than in China in 1979. If we examine the change in the share of services in GDP for about the first twenty years of reform, the share increased by 24.2 percent in China and 21.2 percent in India.

We finally examine social progress in Section V. We find that South Asia lags behind other regions n making progress towards the Millennium Development Goals (MDGs)and India lags behind other South Asian countries. The responsiveness of the improvement in the MDGs to increases in per capita income is usually low in Asia and particularly in India. 


\section{Section II The 1991 Indian Policy Reform}

The 1991 reforms which followed a balance of payment crisis resulted in a fundamental re-orientation of Indian policy unlike what had usually happened in previous crises. Policy adjustments had been made after previous crises but the broad strategy had remained the same. The basic objectives of policy had remained constant since independence: rapid growth, poverty removal, a more equitable income distribution and self-sufficiency ${ }^{1}$ though the relative weights of the different objectives varied over time. These objectives were to be reached through the adoption of an import substituting industrialization strategy in which the state would play a prominent part through its almost total monopoly of production of capital goods and important intermediate goods. ${ }^{2}$ Policy changed as the relative importance of the different objectives varied and when the constraints facing the economy changed. ${ }^{3}$ One of the consequences of the crisis was usually a drop in the investment ratio which recovered only after a considerable lag. For instance, after gross fixed capital formation (GFCF) as a percentage of gross domestic product (GDP) reached a peak of 15.9 per cent in 1957-58 it fell after the 1957-58 BOP crisis and did not recover to the earlier ratio till 1963--64 (RBI 2012). The fall in the GFCF ratio after the 1965-67

\footnotetext{
1 The meaning of self-sufficiency itself has varied over time. Usually it meant ability to resist external pressures to change policies, particularly foreign policies. In the preparation for the Fifth Plan, because of experience since the mid-sixties when aid was sought to be used to pressurize India to change its policies on Vietnam and later on Bangladesh, self-sufficiency was taken to mean reaching a stage where there was no need for aid.

2 Most development analysts in the 1950s e.g. Rosenstein-Rodan (1943), Prebisch (1950), Nurkse (1953), Arthur Lewis (1954), argued for an import substituting industrialization strategy For a discussion of their views see Agarwal (1991). One of the reasons for the state to control these important sectors was to establish a more equitable income distribution. ${ }^{3}$ For instance, self-sufficiency became more important after the cut off of aid because of disagreements over India's policy over Viet Nam (Bowles, 1971) and over the events leading to the creation of Bangladesh. For a discussion of the varying constraints and their effect on policy see Agarwal, 1997.
} 
crisis was particularly severe ---from 20.4 per cent to 16.7 per cent---and it did not recover till 1977-78.

One of the consequences of the many travails the economy faced after the mid-1960s, droughts in 1965-1967, cut-off of aid by the US and the World Bank in 1968, the influx of refugees in 1971 from then East Pakistan and the ensuing war and later the oil and food price increases in 1973, was lower public sector investment resulting in considerable excess capacity in the capital goods sector and very high capital output ratios. ${ }^{1}$ Many policy analysts analyzed this imbalance between the structure of demand and the structure of production and saw increased government investment as a solution (Chakravarty, 1979). Once structural adjustment was complete, the savings rate of both households and the government rose, the government raised its investments. It also stopped running a conservative fiscal policy to raise expenditures and started running deficits and since then budget deficits have been the rule and usually have been large.

Rodrik and Subramaniam (2005) do not believe that these higher government expenditures can explain the improved economic performance in the 1980s. They argue while they may raise GDP they would not have resulted in the higher growth of TFP which is observed in this period. But if the higher growth is because of better capacity utilization then one can expect higher TFP growth unless capacity utilization is taken into account in the measurement of capital. The incremental capital output ratio which was over 6 during the period 1966-73, a period of low growth and considerable excess capacity, dropped to 4 in the 1980s, a figure similar to that in the East Asian region. Also one would expect that in a country with fixed

\footnotetext{
1 The low growth during 1966-1973 in what was essentially a period of structural adjustment implied a low growth over the period 1951-and the mid 1970s and has been dubbed as the 'Hindu rate of growth' despite higher growth in the period from the early 1950s to the mid 1960s. 
exchange rates and no capital flows increased government expenditures would raise income, however, at the expense of increased current account deficits and higher interest rates (Kenen, 2000). The adverse effect of higher interest rates on private investment was sought to be neutralized by fiscal incentives such as accelerated depreciation. Also, development of the capital market meant that much of investments by the large companies were financed by the capital markets rather than banks. The government was able to prevent a sharp drop in corporate investment as a share of GDP; but there was no increase in the 1980s. The increase in investment was almost entirely in the public sector. Also, despite providing a number of incentives to exporters it was not able to prevent the stagnation in the share of exports to GDP and the emergence of an increasing current account deficit which ultimately resulted in the 1991 BOP crisis.

Some analysts believe that liberalization in the 1980s contributed to the improved performance of that period. There was some easing of import licensing for capital goods and some intermediate goods and also for expansion of capacity by large enterprises (Bhagwati, 1993, Panagariya, 2008). But the overall trade regime remained severely protectionist. Tariffs remained high and the effective rates of protection did not fall in the 1980s (Kotwal, Ramaswami and Wadhwa, 2011). Also there was no drop in the percent of manufactured imports subject to non-tariff barriers (Kotwal, Ramaswami and Wadhwa, 2011). There undoubtedly was some liberalization. The open general license (OGL) list which was begun in 1976 with only 79 capital goods in the list covered almost 30 percent imports by 1990 (Panagariya, 2008). But we believe that this liberalization was modest and more in the nature of policy adjustments that are often undertaken by governments. Tariff revenues as a percent of imports remained high. Furthermore, the almost constant share of corporate investment in GDP casts doubt on the effect of loosening 
capacity expansion restrictions on raising growth rates. Rodrik and Subramaniam (2005) ascribe the improvement in the 1980 s not to specific policy changes but to the adoption by the government of a more pro-business attitude which encouraged private sector growth. But since corporate investment did not rise as a share of GDP, which it has since 1991, it is difficult to identify the mechanism through which the government's pro-business policy resulted in higher growth.

Statistical analysis to identify a structural break in GDP growth do not find a break in the mid 1980s. Wallack (2003) finds a break in 1980, Rodrik and Subramaniam (2004) in 1979, Balakrishnan and Parameswaran (2007) in 1979-80, Basu (2008) and Sen (2007) find it in 197576. All show a break before the liberalization of the 1980s. There has been gradual acceleration in growth since the mid 1970s after the adjustment to the various crises beginning in 1965 was completed. The growth of GDP which had fallen to 3.4 percent a year during the Fourth Plan, 1969-73, rose to 5 percent in the Fifth Plan (1974-78) and further to 5.5 percent in the Sixth Plan (1980-84) and 5.6 percent in the Seventh (1985-89) and has continued to accelerate. It is difficult to identify this acceleration with specific policies.

The development strategy was retained till 1991 despite mounting evidence of its harmful effects. Research abroad (Little, Scitovsky and Scott, 1970, Bhagwati, 1978, Krueger, 1978) had shown import substitution policies to be inefficient. Commissions (Abid Hussain, Narasimham) set up by the Government of India had also documented the inefficiencies engendered by the high tariff regime and by the system of licensing that went with it. ${ }^{1}$ Policy makers were convinced that the basic model of import substitution needed a change. ${ }^{2}$ The

\footnotetext{
1 The inefficiencies had been identified and analyzed earlier ( Bhagwati and Desai, 1970, and Bhagwati and Srinivasan, 1975)

2 The high growth rates achieved by China another large economy were more difficult to brush
} 
rationale for a large public sector producing capital goods no longer held since in an open economy there was no equivalence between the size of the capital goods sector and the investment rate. ${ }^{1}$ But the economy had been resilient. The effect of the BOP crises on growth was usually short-lived, despite the slowdown in investment as noted above. The growth rate of GDP fell to -1.2 per cent in 1957--58 before it recovered to 7.6 per cent in the following year. Similarly, the growth rate declined from 4.7 per cent in 1973-74 to 1.3 per cent in 1974-75 before recovering to 9.1 per cent in 1975--76, and declined from 5.5 per cent in 1978--79 to -5 per cent in 1979--80 before increasing to 7.2 per cent in $1980--81 .^{2}$ The exception was the crisis during the years 1965--67 when the interruption in growth was much more substantial, and had resulted in a much greater adjustment of policies than was usually the case.

But policy makers had come to believe that the prevailing model was no longer sustainable and needed to be changed. The 1991 crisis provided the opportunity to bring about a fundamental change in development strategy, an abandonment of the import substitution model, reducing sharply the role of the public sector and much less importance being given to the objective of reducing income disparities. Reliance on the public sector lessened and more importance was accorded to the private sector. This shift coincided with a change in the concern about income distribution. Concern shifted from income distribution as such to reducing poverty

aside than the success of smaller countries such as Kore, Taiwan, Singapore and Hong Kong. 1 The Second Plan's analytical basis was the Mahalanobis model which was of a closed economy and where therefore the savings and investment rate equaled the share of the capital goods sector in total output. The greater the investment in the capital goods sector the larger its share in total output and the higher the savings and investment ratios and higher the growth rate. For a discussion of the Mahalanobis model see Bhagwati and Chakravarty (1969). Also there is a difference depending on whether one assumes that capital is shiftable namely can be used at any time in either the consumer goods sector or the capital goods sector or that it is nonshiftable, namely, once it is alloCated to the consumer goods or the capital goods sector it cannot be shifted to the other sector. see Chakravarty (1969).

2 The large variation in growth rates was due to the effects of the BOP position as well as fluctuations in agricultural output caused by variations in rainfall. 
and improving the condition of the poor. Consequently, the Rural Employment Guarantee Scheme that provided 100 days of employment to each poor rural family was implemented; the Right to Education Act was passed. In 2011, the National Food Security Act 2011, which guarantees subsidised food to $50 \%$ of the urban population and $75 \%$ of the rural population, was proposed. Disputes about its provisions have prevented its enactment as yet.

Tariffs on manufactures were reduced from an average of about 100 percent and a peak of almost 400 percent first to an average of about 30 percent. Currently, the average is under 10 percent (World Bank, 2011). Peaks have also been reduced. Furthermore, QRs which were ubiquitous have been almost eliminated. On agriculture they were converted to tariffs as part of the Uruguay Round Agreement on Agriculture; the remaining QRs had to be eliminated when India lost the dispute brought by the US to the WTO. Licensing has been eliminated; the number of industries reserved for the small scale sector which prevented the setting up of plants of optimal size has been reduced and large enterprises can enter even those reserved for the small scale if at least 50 percent of the output is exported. FDI and portfolio inflows have been liberalized; outward FDI had also been liberalized leading to large outflows by private industry. ${ }^{1}$

${ }^{1}$ Changes in policies are described in the Annual Economic Survey published by the Ministry of Finance every year just before the budget is presented to parliament. 


\section{Section III Growth in the Indian Economy}

The Indian economy has been on an accelerating growth path since the mid 1970s for over three decades (Table 1). The financial crisis of 2008 has resulted in the growth rate becoming more variable. While the crisis lowered the growth rate from $9.7 \%$ in $2007-08$ to 6.5 $\%$ in $2008-09$, the economy recovered quickly to grow at $7.9 \%$ in $2009-10$ and $8.3 \%$ in $2010-$ 11. But the high rate of growth has not been sustained and declined to 7 percent in 2011-12.

Table 1 Growth Rate of GDP and Major Sectors in India

Plans GDP Agriculture Manufacturing Services

$\begin{array}{lllll}6^{\text {Th }}(80-84) & 5.4 & 5.7 & 5.1 & 5.4 \\ 7^{\text {Th }}(85-89) & 5.6 & 2.8 & 6.0 & 6.1 \\ 8^{\text {Th }}(92-96) & 6.6 & 4.7 & 9.4 & 6.8 \\ 9^{\text {Th }}(97-01) & 5.7 & 2.4 & 3.3 & 7.8 \\ 10^{\text {Th }}(02-06) & 7.6 & 2.4 & 9.3 & 10.1 \\ 11^{\text {th }}(07-10) & 7.9 & 3.2 & 7.9 & 10.0\end{array}$

Source Reserve Bank of India 2012.

The acceleration in the rate of growth is partly because of the greater weight that faster growing sectors achieved over the years because of their faster growth. For instance if we apply the growth rates for the sectors during the $11^{\text {th }}$ Plan to the sector shares during the $6^{\text {th }}$ Plan the overall growth rate would be $6.7 \%$. But if we apply the same growth rates to the sector shares in the $11^{\text {th }}$ Plan the overall growth rate is $8.2 \%$ a full $1.5 \%$ greater. The share of the slow growing agricultural sector has been declining (Table 3). But another important feature of the growth 
acceleration is the higher growth rate of the services sector. There has been a sharp acceleration in the rate of growth of value added in services from the eighties to the nineties and further in this century (Table 1).

Is this acceleration in growth of GDP and the faster growth of the services sector significant? The annual rates of growth of output in the agriculture, manufacturing and services sectors and the mean growth rates and the standard deviation in growth rates for the periods 1981-90, 1992-2000 and 2001-10 have been calculated. A comparison of the sector growth rates for the periods 1981-90 and 1992-2000 shows that the difference in average growth rates over the two periods is significant only for services at the $10 \%$ level when a two-tailed t-test is applied. A comparison of sector growth between 1992-2000 and 2000-2010 shows no differences in sector growth rates that were significant, the difference in the growth rates for services was just under the $10 \%$ significance level. When, however, the difference in mean growth rates between the 1981-1990 and 2001-10 periods is tested the difference in the growth rates for services is significant at the $1 \%$ level; the other sector growth rates are not significantly different. So there is an acceleration in the rate of growth of services though this does not happen for the other sectors.

What about the growth rates of the manufacturing and service sectors? The average growth rate for services during the period $1980-1996$ is 6.4 percent, not statistically different from the 6.3 percent growth rate for manufacturing during that period. Again the average growth rates for the two sectors are not significantly different for the period 2002-10, except for the year 2008 (Table 2). The significant difference is during the Ninth Plan (Table 1). The large reduction in tariff rates for imports of manufactures could have resulted in a shrinking of the sector as happened in many Latin American countries where the share of manufactures in GDP has 
declined. In India, seemingly the devaluation of the rupee has compensated for the reduction in protection. The importance of exports has increased for the manufacturing sector. The percent of value of exports to value added in manufacturing has increase from 16.4 percent in the 6th Plan (1980-84) to almost 60 percent in the period 2007-10. This devaluation of the rupee has had an even stronger effect on exports of services and this has contributed to a higher rate of growth for the services sector.

Table 2 Annual Rates of Growth of Indian Value-Added (Per cent) Manufacturing Services

1997 $.05 \quad 8.00$

1998

$3.13 \quad 8.36$

1999

5.39

10.99

2000

7.30

5.37

2001

2.77

6.88

2002

6.87

6.97

2003

6.34

8.06

2004

7.38

8.12

2005

10.10

10.91

2006

14.32

10.06

2007

10.28

10.27

2008

4.33

9.98

2009

9.66

10.45

2010

7.56

9.35

Source World Bank Databank http://databank.worldbank.org/ddp/home.do 
Table 3 Structure of the Indian Economy (\% of GDP)

$\begin{array}{lrcc}\text { Plans } & \text { Agriculture } & \text { Manufacturing } & \text { Services } \\ 6^{\text {Th }}(80-84) & 41.0 & 14.6 & 37.1 \\ 7^{\text {Th }}(85-89) & 36.6 & 15.9 & 40.1 \\ 8^{\text {Th }}(92-96) & 32.3 & 17.1 & 43.1 \\ 9^{\text {Th }}(97-01) & 27.5 & 17.1 & 47.9 \\ 10^{\text {Th }}(02-06) & 19.6 & 15.5 & 52.9 \\ 11^{\text {th }}(07-10) & 18.1 & 15.1 & 54.2\end{array}$

Source Reserve Bank of India 2012.

Despite this acceleration, the share of services in GDP in India, defined as a low middle income country by the World Bank, while higher than the average is not exceptional. The average for low income countries is 50 percent and for low middle income countries is 48 percent. Where India deviates significantly from other low middle income countries is in the share of manufacturing which averages 26 percent for low middle income countries as against India's 15 percent, and this share has come down in the past decade in India. Furthermore, the share of services in GDP increased between $1974-82$ and 2001-10 by 85.3 percent in China whereas it increased by only 32 percent in India. In Korea it increased by over 33 percent in this period. In Malaysia and Indonesia in South East Asia it hardly increased and in Thailand it fell. ${ }^{1}$ Also, the share of manufacturing in GDP fell from 38.0 percent to 32.1 percent in China during this period and in India it fell from 16 percent to 15.2 percent.

\footnotetext{
${ }^{1}$ For a broader analysis of the similarities and differences in economic performance in China and India since the reforms see Agarwal and Whalley (2012).
} 
Table 4 Structure of Demand in India (\% of GDP)

$\begin{array}{lcccc}\text { PLANS } & \text { Household } & \text { Government } & \text { Gross Fixed } & \text { Exports } \\ & \text { Consumption } & \text { Consumption } & \text { Capital Formation } & \text { of G\&S } \\ 6^{\mathrm{Th}}(80-84) & 76.9 & 10.5 & 19.8 & 6.2 \\ 7^{\mathrm{Th}}(85-89) & 71.7 & 12.0 & 22.7 & 5.9 \\ 8^{\mathrm{Th}}(92-96) & 65.4 & 11.0 & 24.3 & 10.2 \\ 9^{\mathrm{Th}}(97-01) & 65.0 & 12.3 & 24.3 & 12.1 \\ 10^{\mathrm{Th}}(02-06) & 59.9 & 11.0 & 27.8 & 17.4 \\ 11^{\text {th }}(07-10) & 57.2 & 11.2 & 31.3 & 21.4\end{array}$

Source World Bank Databank http://databank.worldbank.org/ddp/home.do

The growth acceleration has been accompanied by a shift in the pattern of demand from household consumption to capital formation, which has increased as a share of GDP by about 50 percent since the 1991 crisis and to exports of goods and services (Table 4). ${ }^{1}$ Correspondingly, the share of household consumption in GDP has decreased.

The big change has been in the share of exports in GDP; exports of goods, non-factor services and of labour services have all increased significantly (Table 5). The share of merchandise exports in GDP which had stagnated in the $1980 \mathrm{~s}^{2}$ increased rapidly since 1991 , more than tripling. Remittances from migrant workers, which usually comes under the heading of private transfers, and therefore export of labour services have quadrupled between the $7^{\text {th }}$ and

1 The increase in share of exports in GDP over the first two decades after reform is very similar in China and India (Agarwal and Whalley, 2012).

2 The averages in this case hide the actual pattern which was one of slight decline in the early part of the eighties and some increase in later years. 
$11^{\text {th }}$ Plans. But the really spectacular increase has been in the share of exports of non-factor services (NFS) in GDP and this has more than quintupled. Most of this export has been of phone and internet related services.

Table 5 Indian Exports (\% of GDP)

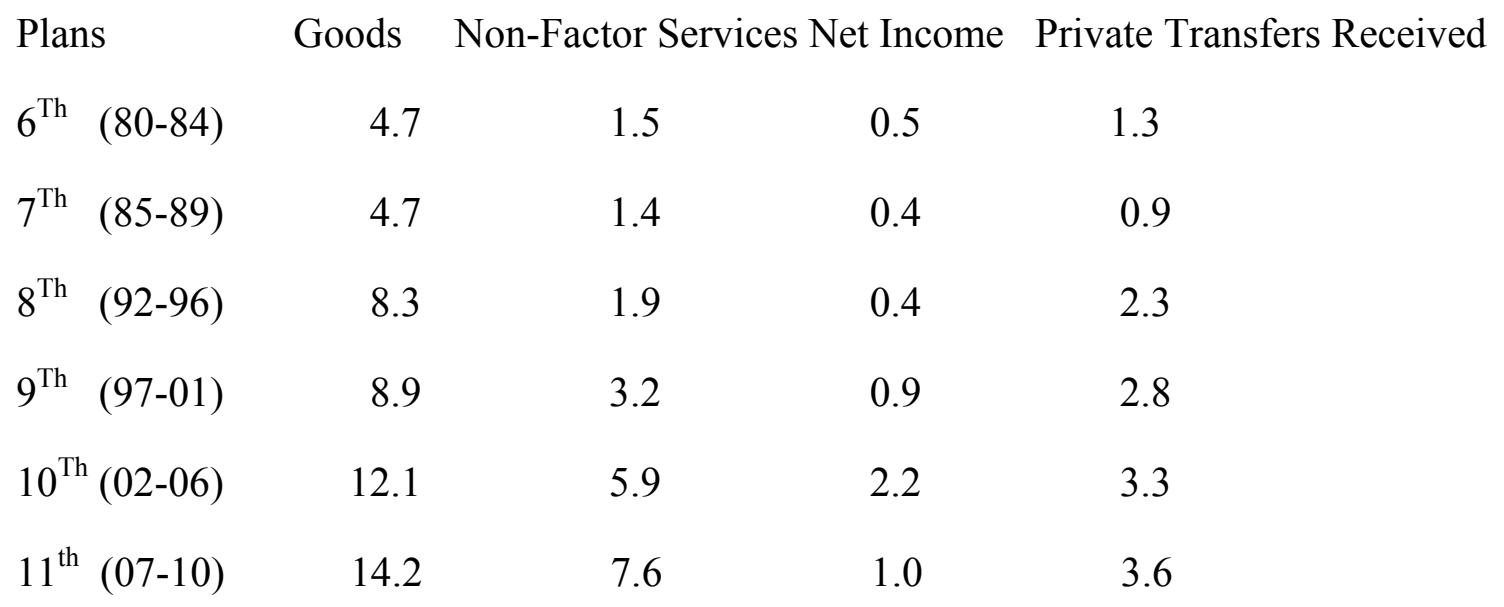

Source Reserve Bank of India 2012.

However, the share of imports of goods as a share of GDP has risen even more, so the deficit in the balance on merchandise trade has increased considerably (Table 6). The deficit in merchandise trade has been increasing since the Eighth Plan and has increased particularly rapidly in the $11^{\text {th }}$ Plan, namely since mainly the financial crisis. But the huge increase in remittances since the Eighth Plan and later the surplus in trade in non-factor services had resulted in a declining current account deficit and even a surplus during some years in the $9^{\text {th }}$ Plan. But the sharp deterioration in the balance on merchandise trade in the Eleventh Plan has resulted in the current account deficit reaching levels it had reached just before the crisis in 1991. The liberalization has not resulted in an improvement in the balance on goods trade; it has, however, resulted in an increasing surplus on trade in non-factor services and in remittances. 
Table 6 Imbalances in Indian Trade (\% of GDP)

Plans Goods Non-factor Services Net Income Private Transfers CAB

$\begin{array}{llllll}6^{\text {Th }}(80-84) & -3.4 & 0.6 & -0.1 & 1.3 & -1.5\end{array}$

$\begin{array}{llllll}7^{\text {Th }}(85-89) & -3.0 & 0.3 & -0.6 & 0.9 & -2.2\end{array}$

$\begin{array}{llllll}8^{\mathrm{Th}}(92-96) & -2.8 & 0.2 & -1.1 & 2.3 & -1.1\end{array}$

$\begin{array}{llllll}9^{\mathrm{Th}}(97-01) & -3.2 & 0.6 & -0.9 & 2.8 & -0.9\end{array}$

$\begin{array}{llllll}10^{\text {Th }}(02-06) & -4.4 & 2.1 & -0.7 & 3.2 & 0.2\end{array}$

$\begin{array}{llllll}11^{\text {th }}(07-10) & -8.3 & 3.2 & -0.5 & 3.5 & -2.2\end{array}$

Source: Reserve Bank of India 2012.

The size of capital flows has also been increasing. Capital flows were negligible before the 1991 crisis. Since then, FDI inflows have increased from 0.35 percent of GDP in the $8^{\text {th }}$ Plan (1992-96) to 2.41 percent in the $11^{\text {th }}$ Plan (2007-10) and portfolio flows increased from .75 percent of GDP to 1.76 percent during this period. FDI flows have been increasing faster than portfolio flows; however, the latter have important implications for policy as discussed below. What is also important is that FDI flows are not a one-way street. Outward FDI has increased from a negligible amount in the 1990 s to 1.23 percent in the $11^{\text {th }}$ Plan. Increasing capital flows are an indication of the ongoing overall integration of the Indian economy with the world economy.

Since the mid-1990s when the exchange rate became market determined the economy has gone through a number of phases. Initially a flexible exchange rate was combined with limited capital mobility. Then capital mobility increased. In the first phase of limited capital 
mobility a high fiscal deficit still resulted in higher interest rates and a higher current account deficit. But since there was limited capital mobility the higher current account deficit translated into a higher balance of payments (BOP) deficit and an exchange rate depreciation which increased exports and so resulted in a still further increase in GDP and growth accelerated. But in the second phase the increase in capital inflows because of the higher interest rates ${ }^{1}$ actually resulted in an appreciation of the exchange rate which slowed the growth of exports and of GDP. Portfolio flows which respond to interest rates are the relevant flows in the above analysis. We see below how portfolio flows separate India from many other developing countries and makes its links more similar to those among developed economies. More recently doubts raised by the large fiscal and current account deficits ${ }^{2}$ have slowed the inflow of portfolio capital and have resulted in a large depreciation of the exchange rate.

An expansionary monetary policy in the US operates on other countries through two channels, the real and financial ones. For the real effect, expansionary monetary policy raises income in the US and increases imports so that exports of partner countries increase, leading to an appreciation of the foreign currency. The financial effect is that the expansionary monetary policy lowers the interest rate in the US leading to capital outflows and an appreciation of the foreign currency which negatively affects exports. The inflow into the other country also lowers its interest rate. So overall there is an appreciation of the currency, a lower interest rate, but the effect on exports is uncertain.

1 The inflows was on account of portfolio investments by foreign investors as well as foreign borrowings by Indian companies as foreign rates of interest rates were lower.

2 The needs of institutional investors for funds in their home markets may have limited their investments in India. 
Interrelations among the $\mathrm{G} 7$ are dominated by the financial effect so interest rates in other G7 countries fall and their exchange rates appreciate following an expansionary US monetary policy. But the response of developing country members is different (Agarwal and Essid, 2012). In the case of emerging economies such as China, Korea and Mexico the exchange rate usually depreciated and there was a weak tendency for the interest rate and for exports to rise. This is because financial linkages are weak in the case of these developing countries and the real effect dominates. Also developing countries are generally adopting an export oriented growth model and so seek to prevent an exchange rate appreciation and actually bring about a depreciation. The depreciation and the increased GDP seem to raise inflation and the interest rate is raised to control the inflation; there is apparently no fear that the higher interest rate would lead to capital inflows. The Indian economy behaves more like the developed economies and not these developing economies, in that the currency appreciates, and the interest rate and exports do not change. The different result is most probably because of the importance of interest sensitive portfolio flows.

The increase in exports raises GDP and with a fixed money supply this would tend to raise the interest rate. In current circumstances policy makers face a difficult choice because of the circularity of processes. Successful economic management results in confidence in the economy and an inflow of capital. This leads to an appreciation of the rupee and a slowdown in exports. This reduces the rate of growth of GDP and increases the current account deficit. These erode confidence and lead to a depreciation of the exchange rate. Policy makers struggle to provide a more stable growth process.

The current account balance (CAB) reflects the changing savings investment balance of the economy. In general the household sector has a surplus of savings over investment while the 
corporate sector and the government have deficits (Table 7). The surplus of household savings had been increasing till the $9^{\text {th }}$ Plan and since has declined. The decline during the $10^{\text {th }}$ Plan was due to a sharp increase in household investment (Table 8); but in the 11tth Plan period the rate of savings declined marginally.

Table 7 Excess of Indian Savings over Investment by Sector

( $\%$ of GDP, Unweighted Annual Average)

PLANS

$6^{\text {Th }}(80-84)$

$7^{\text {Th }}(85-89)$

$8^{\text {Th }}(92-96)$

$9^{\text {Th }}(97-01)$

$10^{\text {Th }}(02-06)$

$11^{\text {th }}(07-10)$
HOUSEHOLD CORPORATE GOVERNMENT

6.8

9.8

10.7

8.7
$-2.9$

$-2.7$

$-4.3$

$-3.0$

$-5.6$

$-8.7$
$-5.9$

$-8.1$

$-6.3$

$-7.2$

$-5.9$

$-6.2$

Source Reserve Bank of India 2012.

Whereas the crisis in 1991 had been preceded by a large deterioration of the government's saving investment balance because of a combination of higher investment (Table 7) and lower savings, the worsening overall savings investment balance in more recent years has been because of the worsening imbalance of the corporate sector (Table7), and because of a sharp increase in investment by the corporate sector (Table 8) which has outpaced the increase in corporate savings. The picture may not look as bleak from the prospect of longer term growth despite the slowdown since the middle of 2011. The higher rates of investment might lead to high rates of growth in the future. But this would require that the $\mathrm{CAB}$ be successfully managed 
in the short run which would require higher savings by both the household and government sectors.

Table 8 Indian Investment by Sector

\begin{tabular}{lccc}
\multicolumn{4}{c}{ (\% of GDP, Unweighted Annual Average) } \\
PLANS & HOUSEHOLDS & CORPORATE & PUBLIC \\
$6^{\text {Th }}(80-84)$ & 5.8 & 4.4 & 10.3 \\
$7^{\text {Th }}(85-89)$ & 7.8 & 4.6 & 11.2 \\
$8^{\text {Th }}(92-96)$ & 6.9 & 8.0 & 8.8 \\
$9^{\text {Th }}(97-01)$ & 10.1 & 6.9 & 6.9 \\
$10^{\text {Th }}(02-06)$ & 14.3 & 11.7 & 7.1 \\
$11^{\text {th }}(07-09)$ & 14.3 & 16.9 & 8.2
\end{tabular}

Source: Reserve Bank of India 2012.

It is also important to note that the share of corporate investment in GDP did not increase in the 1980s, so even if government attitude was more pro-business in the 1980s as claimed by Rodrik and Subramaniam, 2005, it is not reflected in higher investment by the corporate sector. It is therefore difficult to isolate the mechanism by which the pro-business policy raised the growth rate. ${ }^{1}$

\footnotetext{
${ }^{1}$ At that time there was discussion that Mrs Gandhi's government was favouring the new business groups such as Ambanis as against the traditional groups such as the Tatas and the Birlas so Rodrik and Subramaniam's claim that existing large businesses were favoured and benefitted may not be true.
} 


\section{Section IV Reforms and Economic Performance}

What difference have the reforms made to economic performance? We try to answer this question by studying the behavior of a number of indicators during the three decades, of the 1980s, the 1990s and the first decade of the new century.

Table 9 Average Performance and its Variability

\begin{tabular}{lcccccc} 
& \multicolumn{3}{c}{ Average } & \multicolumn{3}{c}{ Standard Deviation } \\
& $1981-90$ & $1992-2000$ & $2000-10$ & $1981-90$ & $1992-2000$ & $2000-10$ \\
& & & & & & \\
& & & & & & \\
PC GDP Growth Rate & 3.25 & $4.13^{* *}$ & $5.87^{* *}$ & 2.35 & 2.19 & 2.23 \\
XGS (\% of GDP) & 5.92 & 10.49 & 18.60 & 2.77 & 1.05 & 3.61 \\
XGS Growth Rate & 5.40 & $13.01^{*}$ & $14.68^{* *}$ & 6.96 & 8.96 & 9.88 \\
Remittances (\% of GDP) & 0.99 & 1.96 & 3.15 & 0.78 & 0.55 & 0.43 \\
CA Balance (\% of GDP) & -1.67 & -1.08 & $-0.72^{* *}$ & 0.49 & 0.46 & 1.45 \\
GFCF (\% of GDP) & 20.98 & $23.08^{* *}$ & 29.11 & 8.17 & 0.88 & 3.23 \\
GFCF Growth Rate & 6.95 & $6.8^{* *}$ & $11.34 * *$ & 5.14 & 6.17 & 6.82 \\
GDS (\% of GDP) & 21.01 & $22.85 * *$ & 29.42 & 8.09 & 1.25 & 3.62 \\
Private Capital (\% of GDP) & & 1.03 & 1.95 & & 0.61 & 0.83 \\
FDI (\% of GDP) & 0.04 & 0.49 & 1.64 & 0.55 & 0.27 & 0.88 \\
ODA (\% of GNI) & 0.72 & $0.49 * *$ & 0.19 & 0.68 & 0.23 & 0.08 \\
ODA (\% of GCF) & 3.49 & 2.00 & 0.64 & 1.36 & 1.10 & 0.39 \\
** t-test Significant at 10\% * Not Significant & & & &
\end{tabular}


When we compare economic performance over the three decades we find that the behavior of the indicators is in line with the government's objectives (Table 9). The rate of growth of per capita GDP was higher in the decade of the 1990s as compared to that in the 1980s, and further increased in the first decade of the 2000s. This growth acceleration was accompanied by a higher investment rate financed to a large extent by a higher rate of domestic saving as the current account deficit (CAD), except more recently, decreased as a percent of GDP. The improvement in the current account balance $(\mathrm{CAB})$ was because of a rapid increase in exports of goods and services and in remittances. Furthermore, the smaller CAD was financed more by private capital inflows, including FDI, rather than aid. The importance of aid declined so if selfsufficiency was an objective of the government it was successful in achieving its goal.

The standard deviation of most of the series increased (Table 9); but this was mainly because these indicators had an increasing trend. The coefficient of variation decreased for most of the indicators except for the current account balance as a percentage of GDP and for ODA as a percentage of gross capital formation (Table 10). 
Table 10 Coefficients of Variation

$\begin{array}{lccc} & 1981-90 & 1992-2000 & 2000-10 \\ \text { PC GDP Growth Rate } & 0.72 & 0.53 & 0.38 \\ \text { XGS (\% of GDP) } & 0.47 & 0.10 & 0.19 \\ \text { XGS Growth Rate } & 1.29 & 0.69 & 0.67 \\ \text { Remittances (\% of GDP) } & 0.78 & 0.28 & 0.14 \\ \text { CA Balance (\% of GDP) } & -0.29 & -0.42 & -2.02 \\ \text { GFCF (\% of GDP) } & 0.39 & 0.04 & 0.11 \\ \text { GFCF Growth Rate } & 0.74 & 0.89 & 0.60 \\ \text { GDS (\% of GDP) } & 0.38 & 0.05 & 0.12 \\ \text { Private Capital (\% of GDP) } & & 0.59 & 0.42 \\ \text { FDI (\% of GDP) } & 12.37 & 0.55 & 0.54 \\ \text { ODA (\% of GNI) } & 0.94 & 0.48 & 0.44 \\ \text { ODA (\% of GCF) } & 0.39 & 0.55 & 0.61\end{array}$

The decrease in the latter case was because of a sharp fall in the average of gross capital financed by aid as the standard deviation actually decreased. The means of most of the variables show an increase from the period 1981-90 to $1992-2000$ and a further increase in the period 2001-2010. We next examine whether these increases in the means are significant. When the period 1992-2000 is compared to the period 1981-90 we find that for 6 of the indicators the difference in means is significant at the $5 \%$ level using a two-tailed t-test, in one case the difference is significant at the $10 \%$ level and in 5 cases it is not significant (Table 9). When we examine the difference in means between 1992-2000 and 2001-10, the difference is significant for 8 of the indicators at the $5 \%$ level, and for 4 it is not significant. Surprisingly, the difference 
in growth rates of per capita GDP is not significant either for the period 1992-200 when compared to 1981-90 or when compared to 2001-10. We also find that the improvement in the CAB was significant between the 1980s and the 1990s but when the 1990s are compared to the 2000s. So the improvement in the CAB was short lived.

We can then compare the means for the period 1981-90 to the means in the period 200110. The difference in means is now significant at the $5 \%$ level for almost all the variables except the current account balance which is significant at the $10 \%$ level. The only variable which shows no significant difference in means is the rate of growth in gross fixed capital formation. This suggests that in many cases the effect of the policy change was slow acting so that there is less change between consecutive decades than over a longer period. Also since there seemed to be change in more variables in the second decade after the reforms than in the first decade there may be an accelerating effect of policy change. 


\section{Section V Social Progress}

A major objective of policy making in India has been to reduce poverty. Though poverty has been decreasing and there is an improvement in many other social indicators, included in the Millennium Development Goals (MDGs), progress has lagged in South Asia as compared to other regions and within South Asia India has lagged (Table 11).

Table 11 Regional Social Improvement (\% decline 1990-2005)

Poverty rate Malnourishment* Infant Mortality Child Mortality Maternal Mortality

$\begin{array}{lccccc}\text { EAP } & 69.3 & 4.4 & 45.6 & 49.9 & 50.0 \\ \text { LAC } & 27.4 & 7.3 & 53.0 & 55.2 & 35.2 \\ \text { MNA } & 16.3 & 5.2 & 50.0 & 54.6 & 53.2 \\ \text { SA } & 22.1 & 4.7 & 37.0 & 41.9 & 47.6 \\ \text { SSA } & 11.6 & 11.6 & 24.7 & 26.6 & 18.4 \\ \text { Bangladesh } & 31.6 & 22.9 & 50.4 & 55.1 & 51.7 \\ \text { India } & 21.5 & 14.2 & 31.8 & 35.3 & 50.9 \\ \text { Nepal } & & & 51.3 & 56.1 & 49.4 \\ \text { Pakistan } & 67.4 & 16.3 & 24.1 & 26.7 & 40.8 \\ \text { Sri Lanka } & 55.8 & 24.2 & 36.2 & 39.8 & 50.6\end{array}$

- The decline in malnourishment is for the period 2000-08. Also for South Asia the individual country numbers seem to be at variance with the figure for the region.

- EAP is East Asia and Pacific, LAC is Latin America and Caribbean, MNA is Middle East and North Africa, SA is South Asia and SSA is Sub-Saharan Africa. The regions are as defined by the World Bank. 
The elasticity of reduction with respect to growth of per capita GDP has been low in Asia, except for the elasticity of reduction of poverty with respect to growth of per capita GDP in East Asia. Again within South Asia this elasticity has been low in India.

Table 12 Elasticity of Reduction with respect to growth of per capita GDP

$\begin{array}{lcrrr}\text { PR } & \text { Malnourishment } & \text { IMR } & \text { CMR } & \text { MMR } \\ \text { 1990-05 } & 2000-08 & 1990-2005 & 1990-2005 & 1990-2005\end{array}$

$\begin{array}{lccccc}\text { EAP } & 1.1 & .07 & 0.4 & 0.5 & 0.6 \\ \text { LAC } & 1.4 & .39 & 2.6 & 2.8 & 1.9 \\ \text { MNA } & .6 & .24 & 2.0 & 2.2 & 2.7 \\ \text { SA } & .4 & .12 & 0.6 & 0.7 & 1.0 \\ \text { SSA } & 1.9 & .55 & 0.8 & 0.9 & 0.8 \\ \text { Bangladesh } & .8 & 1.0 & 1.5 & 1.7 & 1.6 \\ \text { India } & .3 & .4 & .6 & .7 & 1.1 \\ \text { Nepal } & & & 2.4 & 2.7 & 2.2 \\ \text { Pakistan } & 3.8 & 1.8 & 0.9 & 1.1 & 1.8 \\ \text { Sri Lanka } & 1.3 & 0.8 & 0.8 & 0.8 & 1.2\end{array}$

Source calculated from data in World Bank World Development Indicators World Bank Databank. 


\section{Section V Concluding Remarks}

We find that the Indian economy has been increasingly integrated with the world economy since the reforms started in 1991. The importance of exports of goods, non-factor services and labour services has increased. There are increasing capital inflows as well as outward FDI. Closer integration of financial markets has important implications for the conduct of economic policy in India.

The behaviour of 12 economic indicators shows that the economy has done better after the reforms, in terms of the level of these indicators and also their reduced variability so that the economy seems to have become stable. While the growth rate of the services sector has increased after the reforms the growth rates of the manufacturing and service sectors are very similar except for the period of the $9^{\text {th }}$ Plan (1997-2001).

The behaviour of exports, growth of manufacturing and services sectors, FDI, all point to greater similarity in economic performance between China and India than difference, if the performance is judged with respect to the year of the reform, 1979 for China and 1991 for India.

South Asia has lagged behind other regions in the extent of social improvement. Furthermore, India has lagged within South Asia. The elasticity of improvement_in social indicators with respect to growth of per capita GDP has been low in India. 


\section{References}

Agarwal Manmohan (1997) Liberalization of the Indian Economy in P.Desai (ed.) Going Global, Camb. Mass., M.I.T. Press, 1997.

Agarwal Manmohan (1991) Trade and Development : A Review of the Issues in D.Banerji (ed.) Essays in Economic Analysis and Policy : Essays in Honour of B.Datta, Delhi, OUP..

Agarwal Manmohan and John Whalley (2013) China and India : Reforms and the Response;

How Differently have the Economies Behaved? Mimeo, Centre for International Governance Innovation, Waterloo, Canada.

Balakrishnan Pulapre and M. Parameswaran (2007) Understanding Economic growth in India : A Pre-reuisite, Ecconomic and Political Weekly, Vol. 42 No. 27-28, p2915-22

Basu Kaushik (2008) the Enigma of India's Arrival : A review of Arvind Virmani's Propelling India : From Socialist Stagnation to Global Power, Journal of Economic Literature, Vol. 46 No, 2, p396-406.

Bhagwati Jagdish (1978) Anatomy and Consequences of Exchange Control Regimes, Camb. Mass. Ballinger Publishing Company.

Bhagwati Jagdish (1993) India in Transition : Freeing the Economy, Oxford, Clarendon Press.

Bhagwati Jagdish and Sukhamoy Chakravarty (1969) Contributions to Indian Economic Analysis, American Economic Review Vol. 59 No. 4.

Bhagwati Jagdish and Padma Desai (1970) India : Planning for Industrialization, London, Oxford University Press.

Bhagwati Jagdish and T.N.Srinivasan (1975) Foreign Trade Regimes and Economic Development : India. New York, Columbia University Press.

Bowles Chester (1971) Promises to Keep : My Years in Public Life, New York, Harper Row.

Chakravarty Sukhamoy (1969) Capital and Development Planning, Camb. Mass. MIT Press.

Chakravarty Sukhamoy (1979) On the Question of Home Market and Prospects for Indian Growth, Economic and Political Weekly, Vol. 14 No. 30/32, August 1979.

Kenen Peter (2000) The International Economy, Camb. Cambridge University Press.

Kotwal Ashok, Bharat Ramaswami and Wilima Wadhwa (2011) Economic Liberalization and Indian Economic Growth : What's the Evidence?, Journal of Economic Literature, Vol. 49 No.4, p 1152-1199.

Krueger Anne (1978) Liberalization Attempts and Consequences, Camb. Mass. Ballinger Publishing Company. 
Lewis W. Arthur (1954) Economic Development with Unlimited Supplies of Labour, Manchester School of Economics and Social Studies, Vol. 22 p139-91.

Little Ian, Tibor Scitovsky and Maurice Scott (1970) Industry and Trade in Some Developing Countries, London, Oxford University Press for the O.E.C.D. Development Center,

Nurkse Ragnar (1953) Problems of Capital Formation in Underdeveloped Countries, Clarendon Press. Oxford.

Panagariya Arvind (2008) India the Emerging Giant, Oxford and New York, Oxford University Press.

Prebisch Raul (1950) The Economic Development of Latin America and its Principal Problem, N.Y. United Nations.

Reserve bank of India (2012) Handbook of Statistics on Indian Economy 2011-12, Mumbai, Reserve Bank of India.

Rodrik Dani and Arvind Subramaniam (2004) Why India can Grow at 7 percent a Year or More : Projections and Reflections, Economic and Political Weekly Vol. 39 No. 16 p 1519-26.

Rodrik Dani and Arvind Subramaniam (2005) From 'Hindu Growth' to Productivity Surge : The Mystery of the Indian Growth Transition, IMF Staff Papers, Vol. 52 No.2 p 193-228.

Rosenstein-Rodan Paul (1943) Problems of industrialisation of eastern and south-eastern Europe, Economic Journal Vol 53, vol. 210/11, p202-11.

Sen Kunal (2007) Why Did the Elephant Start to Trot? India's Growth Acceleration Re-Examined, Economic and Political Weekly Vol. 42 No. 43 p 37-47.

World Bank (2011) World Development Indicators, World Bank, Washington D.C. 